KATARZYNA SZYMALA

Szkoła Podstawowa, Gimnazjum i Liceum Ogólnokształcące

\title{
DZIAŁANIE CZŁOWIEKA JAKO KATEGORIA RÓŻNICUJĄCA I JEJ IMPLIKACJE DLA PEDAGOGII
}

Streszczenie: Celem artykułu jest wskazanie na podstawie tekstu Osoba i czyn Karola Wojtyły na zasadność powrotu do personalistycznej koncepcji działania osoby jako tradycji myślenia niezbędnej do przywrócenia znaczenia wychowaniu we współczesnym kontekście kulturowym. Punktem wyjścia rozważań jest stwierdzenie, że wpisanie edukacji w dominujący w przestrzeni publicznej neoliberalny, technologiczny oraz eugeniczny kontekst redukuje pojęcie działania edukacyjnego. Przywołane konteksty łączy rozumienie kształcenia jako działania nastawionego bardziej na wynik niż na sam proces, dążącego do ulepszenia procesu edukacyjnego czy wręcz do przejęcia nad nim kontroli. Tylko wtedy, gdy przyjmie się - wbrew postulatom transhumanizmu - że działanie człowieka jest kategorią różnicującą, to znaczy, że rzeczywiście różni się ono od aktywności zwierząt czy maszyn, możliwa jest obrona jego racjonalności w obszarze wychowania.

Słowa kluczowe: filozofia działania, personalizm, wychowanie, samowychowanie, neoliberalizm, eugenika, cyborgizacja edukacji

Myślenie o edukacji charakteryzuje obecnie zderzanie się różnorodnych tendencji, oczekiwań społecznych i strategii politycznych. Ten ideowy zamęt ujawnia się między innymi - w sprzecznych językach opisu czy różnych punktach odniesienia, w których lokowana jest debata o edukacji. Z jednej strony, wysuwane są postulaty uprawiania pedagogiki osoby i traktowania uniwersytetu jako wspólnoty wartości, z drugiej - kształcenia na potrzeby rynku oraz ewaluacji pracy szkoły za pomocą edukacyjnej wartości dodanej ${ }^{1}$. Wielogłosowość w tym obszarze nie jest oczywiście

${ }^{1}$ Należy tutaj wspomnieć o arcyciekawym tomie z serii Palace problemy edukacji i pedagogiki pod tytułem Fabryki dyplomów czy universitas? O „nadwiślańskiej” wersji przemian w edukacji akademickiej, który ukazał się pod redakcją Marii Czerepaniak-Walczak (Czerepaniak-Walczak 2013). Warto zwrócić szczególną uwagę na teksty: Neoliberalna restrukturyzacja fabryki edukacyjnej oraz Uniwersytet - przedsiębiorstwo produkcyjno-ustugowe, student - klient supermarketu? Czyli szkolnictwo wyższe w procesie zmian. 
zjawiskiem nowym. Więcej, można powiedzieć, że jest niejako wpisana w specyfikę edukacyjnych rozważań ${ }^{2}$. Za nowy można natomiast uznać fenomen radykalizowania się i jednoczesnego wykluczania wysuwanych wobec szkoły oczekiwań oraz coraz większą presję zewnętrzną, jakiej poddawana jest pedagogika. Osłabienie krytycznej, autonomicznej refleksji nad procesem kształcenia skutkuje wewnętrznie zróżnicowanymi, niespójnymi kontekstami dla edukacji.

Punktem wyjścia prowadzonej w tym artykule analizy jest teza o zróżnicowanym i pozanormatywnym (wykraczającym poza właściwy dla pedagogiki obszar) typie myślenia, racjonalności oraz działaniach przypisywanych edukacji jako zjawiskach pożądanych. Na potrzeby pracy zastosowano trojaki kontekst: ekonomiczny, cyborgiczny oraz eugeniczny. Należy zaznaczyć - to istotna uwaga - że są one niewspółmierne zarówno ze względu na siłę ich społecznego oddziaływania, obecność tematów, jakie wchodzą w ich zakres, w sferze publicznej, jak również możliwość ich zastosowania w edukacji czy zakres prowadzonych nad nimi badań. Świadomy dobór i zaznaczenie istnienia tych właśnie fenomenów ma służyć eksplikacji szerszego zjawiska, wykraczającego tym razem poza konkretną dyscyplinę pedagogiczną ${ }^{3}$.

Pierwszy z kontekstów przywołuje koncepcję ideologii neoliberalnej, która wprowadza w obszar kształcenia reguły rządzące wolnym rynkiem, globalny kapitalizm, pojęcie klientów i edukacyjnych produktów. W tym ujęciu „wiedza i umiejętności są cenione o tyle, o ile dadzą przełożyć się na konkretny zysk finansowy, czyli dobrze płatną pracę i dobra świadczące o statusie społecznym jednostki” (Michałowska 2013, s. 130). Drugi, cyborgiczny kontekst, odnosi się bezpośrednio do terminu „cyborgizacja edukacji”, skonceptualizowanego niedawno przez badaczy. Oznacza on „proces rozszerzania rzeczywistości poprzez technologie wzmacniania i ulepszania zdolności poznawczych człowieka" (Klichowski, Przybyła 2013, s. 151). Trzeci, najbardziej radykalny wątek, przywołuje postulat zastąpienia tradycyjnego procesu wychowania opartego na komunikacji (czyli na rozmowach, działaniu

${ }^{2}$ Doskonałym przykładem tego, jak różnie bywa postrzegana rola edukacji, wychowania oraz jak odmienne wartości są im przypisywane, jest książka Filozoficzne i ideologiczne podstawy edukacji (Gutek 2007).

${ }^{3}$ Rozmieszczone w pracy akcenty służą przede wszystkim zaznaczeniu różnicy między działaniem człowieka - jego czynem - a aktywnością maszyn czy zwierząt. Skutkuje to tym, że przywołane pozaedukacyjne konteksty opisane są w mocno syntetyczny sposób, co może prowadzić do niezamierzonych uproszczeń czy jednostronnych ocen. W odniesieniu do cyborgizacji edukacji trzeba wyraźnie zaznaczyć, że brakuje opracowań dotyczących istotności tego procesu dla edukacji oraz wyników potwierdzających, że cyborgizacja - proces rozszerzania możliwości zwiększa efektywność szeroko rozpatrywanego uczenia się (Klichowski, Przybyła 2013, s. 146). Z kolei neoliberalne rozumienie kształcenia jako przygotowywania uczniów do radzenia sobie z wyzwaniami rynku pracy jest, skądinąd, zjawiskiem pozytywnym, odpowiadającym uwarunkowaniom społeczno-rynkowym. 
„przez mówienie”) ingerencją w genotyp człowieka ${ }^{4}$. Praktycznym tego wyrazem ma być zastosowanie inżynierii genetycznej poprzez selekcję zarodków $\mathrm{w}$ fazie preimplantacyjnej ${ }^{5}$. Co podobnego pojawia się w zarysowanych tendencjach wkraczających w edukacyjny dyskurs?

Wymienione powyżej nurty łączy specyficzne rozumienie kształcenia jako działania nastawionego bardziej na wynik niż na sam proces, dążącego do ulepszenia procesu czy wręcz do przejęcia nad nim kontroli - jak w przypadku zastąpienia edukacji i wychowania manipulacją genetyczną ${ }^{6}$. W tej perspektywie mieści się przede wszystkim (jeśli nie jedynie) aktywność podmiotu nastawiona na konfrontację, policzalność i wymierzalność efektów, czyli swego rodzaju działanie zewnętrzne ${ }^{7}$. Nie pozostaje to bez znaczenia dla rozważań o pedagogii ${ }^{8}$, czyli praktyce wychowania. Zarówno wychowanie, jak i samowychowanie zakładają ponadto, że jest możliwy niesterowalny z zewnątrz, niepoddający się deterministycznym zasadom fenomen działania człowieka jako osoby wolnej. Co więcej, samo zjawisko aktywizacji wychowawczej jednostki jest uważane ze społecznie znaczące: liczy się w nim nie tylko wynik, lecz również sam proces.

Celem niniejszej pracy jest wskazanie na zasadność powrotu do personalistycznej koncepcji działania osoby jako kluczowej, by nie powiedzieć - nieodzownej, kategorii do przywrócenia znaczenia wychowaniu i samowychowaniu we

${ }^{4} \mathrm{~W}$ tym miejscu dokonuje się świadomego uproszczenia, stawiając znak równości między genetyką a eugeniką. To oczywiste, że nie każdemu działaniu genetycznemu towarzyszy intencja eugeniczna. Więcej na ten temat można znaleźć w książce Michała Klichowskiego (Klichowski 2014).

${ }^{5}$ Pomysł powiązania genetyki z edukacją i wychowaniem wydaje się nieco kuriozalny, choćby ze względu na skrajnie odmienną metodologię oraz intencjonalność obu dyscyplin. Być może jest to jednak przejaw ruchu inicjującego ideowe przesunięcie zarówno wizji kształcenia, jak i percepcji sposobu oraz możliwości rozwoju osoby.

${ }^{6}$ Jak pisze Michał Klichowski, „narodziny cyborgizacji uzmysławiają nam ponadto, że edukacja jest potrzebna tylko w sytuacji, gdy człowieka definiujemy jako niedoskonałą wypadkową interakcji przypadkowej kombinacji genetycznej ze środowiskiem, wymagającą ukierunkowanego kształtowania i stymulowania. W chwili, w której człowiek rodzi się jako „genetyczny ideał”, a jego funkcje mogą być z łatwością rozszerzane poprzez technikę, edukacja przestaje być potrzebna - obszar jej działalności staje się działką inżynierów genetycznych oraz kognitywistów, programistów, konstruktorów itp. W takich warunkach (regułach formacyjnych) idea edukacji znika (rodzi się formacja dyskursywna zmierzchu edukacji)" (Klichowski 2014, s.163).

7 Jak zauważa Zdzisław Wołk, w „neoliberalnej rzeczywistości edukacja postrzegana jako proces ma charakter coraz bardziej instrumentalny, zalgorytmizowany, jej rezultaty są weryfikowane w sposób mechaniczny i często bezduszny. Jest jednym z elementów sformalizowanej machiny biurokratycznej. Prowadzi do optymalizowania wykształcenia pod kątem spełniania określonych standardów. Rozwój własny staje się natomiast w coraz większym zakresie sprawą samego zainteresowanego i jego najbliższych" (Wołk 2005, s. 78).

8 Według Zbigniewa Kwiecińskiego „pedagogia to całkowity obszar myślenia o wychowaniu i praktyce edukacyjnej" (Kwieciński 2012, s. 9). To znaczenie terminu zostało przyjęte w pracy. 
współczesnym kontekście kulturowym. Tylko wtedy, gdy działanie człowieka ${ }^{9}$ jest kategorią różnicującą, to znaczy rzeczywiście różni się od aktywności zwierząt czy maszyn, możliwa jest obrona racjonalności ludzkiego działania w obszarze wychowania. Ten rodzaj działania zwykle nie ma znamion wymierzalnego sukcesu, może zakończyć się porażką, a nade wszystko wyraża się w mozolnej pracy nad sobą i wielokrotnie ponawianym wysiłku zmiany, niekoniecznie dostrzeganej od razu przez otoczenie. Na pytanie o to, dlaczego działanie człowieka może stanowić kategorię różnicującą w pedagogice, wstępnie można odpowiedzieć następująco: po pierwsze, „działanie edukacyjne jest działaniem etycznym, czyli takim, które zachodzi między ludźmi, a nie między człowiekiem a przedmiotem" (Zamojski 2010, s. 335). Po drugie, „jeśli chcemy rozpoznać działanie edukacyjne jako kwestię etyczną, trzeba je przede wszystkim rozpatrzyć jako praktykę, a nie jako technikę" (Zamojski 2010, s. 336). Po trzecie, według personalistycznego ujęcia to, co specyficznie ludzkie, co stanowi o byciu osobą, ujawnia się w działaniu. I wreszcie, po czwarte, pedagogika tradycyjnie uznawana jest za domenę humanistycznej refleksji, w której centrum znajduje się człowiek i różnorodne interakcje (działania), jakie podejmuje $^{10}$.

Nie ulega wątpliwości, że określona wizja antropocentryczna odsłania się w analizie działania człowieka. Takie analizy prowadzić trzeba, szczególnie w obszarze humanistyki, gdzie - ujmując problem metaforycznie - „różnica stała się tożsamością”. Coraz częściej wątki transgatunkowe (poszukiwanie podobieństw między działaniem ludzi, zwierząt i maszyn) przenikają do dyskursu naukowego, tworząc nowe ramy i punkty odniesienia czy w ogóle nową problematykę wychodzącą poza tradycyjnie zarysowane granice poszczególnych dyscyplin. Jednak nie interdyscyplinarne ujęcie stanowi o istocie problemu. Wyzwanie naukowe - przy jednoczesnym pielęgnowaniu otwartości na nowe kierunki badawcze - polega na zachowaniu differentia specifica: działanie najinteligentniejszych maszyn czy

9 Osią prowadzonych w artykule rozważań jest ujęcie edukacji i wychowania jako swoistego działania osoby. Trzeba zaznaczyć, że dla Karola Wojtyły działanie człowieka jest specyficznym działaniem i zarazem czymś więcej niż tylko działaniem. Jak sam pisze: „Fakt «człowiek działa» w swej pełnej doświadczalnej zawartości pozwala się w ten sposób zrozumieć: pozwala się mianowicie zrozumieć jako czyn osoby. [...] Czyn niewątpliwie jest działaniem. Działanie odpowiada różnym działaczom. Jednakże takiego działania, które jest czynem, nie możemy stanowczo przypisać żadnemu innemu działaczowi - tylko osobie. W tym ujęciu czyn zakłada osobę" (Styczeń i in. 1994, s. 58-59). Wydaje się zatem uzasadnione stosowanie terminu „działanie człowieka” w połączeniu z dopełniającym go określeniem „kategoria różnicująca”. W pracy przyjmuje się konsekwentnie rozumienie działania jako wtórnego aktu bytu, aktywności, która pochodzi sprawczo od człowieka. „Jeśli sprawczość bierze się z woli człowieka zmierzającego świadomie do poznanego celu, zwie się je aktem ludzkim (actus humanus)" (Podsiad 2000, s. 20). Autorka niniejszego tekstu dziękuje Witoldowi Starnawskiemu za zwrócenie uwagi na konieczność zaznaczenia różnicy między działaniem a czynem.

10 Poza nurtem prowadzonych rozważań pozostaje kwestia formalnej przynależności pedagogiki do dziedziny nauk społecznych bądź humanistycznych. 
najbardziej rozwiniętych zwierząt nigdy nie stanie się czymś ludzkim. Natomiast człowiek może się w działaniu zdehumanizować, dlatego tym bardziej zasadne jest postulowanie humanizacji edukacji.

Każda praca badawcza nawiązuje do określonej tradycji filozoficznego myślenia. Inspiracją teoretyczną tego artykułu jest personalistyczna myśl Karola Wojtyły zawarta w jego pracy Osoba i czyn ${ }^{11}$, a szczególnie wspomniana już kategoria działania osoby, jako organizująca prowadzone rozważania. Współczesna filozofia przywiązuje dużą wagę do tej kategorii, nadając jej nowe znaczenia i konotacje. Przykładem tendencji zrównującej działania w różnych kontekstach gatunkowych, a więc wykraczającej poza klasyczne rozumienie działania osoby, jest transhumanizm.

\section{Transhumanizm - ramy nowego myślenia o osobie}

Za transhumanizm uważa się obecnie nurt filozoficzny, dokonujący „reorganizacji" gatunków w hierarchii bytów. Jest to w istocie nowa propozycja nieantropocentrycznej wykładni, w myśl której dotychczasowy wyjątkowy status człowieka w świecie zostaje zakwestionowany czy wręcz uchylony. Zdaniem przedstawicieli tego kierunku nie ma powodu, żeby inne byty ożywione - zwłaszcza zwierzęta, a nawet sztuczne inteligencje nie były przedmiotem szczególnej refleksji i nie miały pod pewnymi względami jeśli nie przewyższać, to z pewnością dorównywać zdolnościom właściwym osobom (Bakke 2010).

Tendencja ta, ideowo zbliżająca się do zjawiska cyborgizacji edukacji, znacząco zawęża pojęcie działania do aktywności, która ma swój początek w celowości zewnętrznej. Tradycyjnie ujmowano intencjonalność jako zdolność do wyznaczania sobie celów w sposób wolny, niezależnie od kontekstu, w jakim znajduje się podmiot. Jeśli fundamentalna różnica między zwierzętami a osobami tkwi w różnych korzeniach ich dynamizmu - instynktownym albo wolnościowym, to wyrzucenie tej różnicy poza nawias czyni problematycznym samo ujęcie działania. W konsekwencji różnica zaznaczająca się bądź na poziomie natury, czyli konieczności, bądź na poziomie wolnego stanowienia o sobie jednostek rozumnych zostaje rozmyta. Poza nawias transhumanistycznych rozważań zostają również przeniesione dwie inne kategorie. Chodzi tutaj z jednej strony o pojęcie procesualności rozumianej jako ciąg świadomych zmian, które są istotne w rozpatrywaniu wychowania i samowychowania, a z drugiej strony - o klasyczną formułę tak zwanych aktów wewnętrznych, typowych dla osoby jako takiej i nawiązujących do jej personalistycznego ujęcia.

Osłabienie czy wręcz zniwelowanie znaczenia tych pojęć nie pozostaje bez wpływu na obszar wychowania. Dzieje się tak dlatego, że rozumienie osoby (jej wnętrza, rodzaju doznawanych przez nią przeżyć, kategorii dóbr, ku którym się kieruje) skorelowane jest $\mathrm{z}$ rozumieniem wychowania. W klasycznym ujęciu

${ }^{11}$ W pracy wykorzystano drugie wydanie z 1985 roku (Wojtyła 1985). 
wychowania za punkt wyjścia przyjmuje się samo stawanie się osoby, identyfikowane zresztą z kategorią fieri. Dynamizm bycia osobą oznacza wartość samej zmiany oraz związanej z nią procesualności. To być może niezbyt fortunne określenie, gdyż wywołuje konotacje dehumanizujące, związane z produkcją. Niemniej oddaje jakąś prawdę o specyfice i odmienności ludzkiego działania. Osoba wyraża się w samym działaniu ${ }^{12}$, ale nie tylko w tym, co zrealizowała. Warto przytoczyć kilka najbardziej typowych ujęć edukacji, które sytuują się w przywołanym tutaj kontekście.

I tak według Czesława Kupisiewicza edukacja to „ogół procesów i zabiegów oświatowych oraz wychowawczych - przede wszystkim zamierzonych, lecz również okazjonalnych - których celem jest wyposażenie wychowanka w wiedzę i umiejętności, a także ukształtowanie jego osobowości stosownie do uznawanych w danym społeczeństwie wartości i ideału wychowawczego" (C. Kupisiewicz, M. Kupisiewicz 2009, s. 40). Spośród różnych propozycji rozumienia tego terminu Bogusław Śliwerski przywołuje znaczenie edukacji jako „procesu permanentnego uczenia się człowieka, przez całe życie” (Śliwerski 2003, s. 905-906). Klasycy wychowania, tacy jak Kazimierz Sośnicki czy Stefan Kunowski, mówią wprost o wychowaniu jako „długotrwałym ciągu zmian” (Sośnicki 1967, s. 3 i 7; Kunowski 2004, s. 166). Badacze zwracają wreszcie uwagę na charakterystyczne cechy procesu wychowania, takie jak: „intencjonalność, interakcyjność, długofalowość” (C. Kupisiewicz, M. Kupisiewicz 2009, s. 193). W tym obszarze - działania intencjonalnego ${ }^{13}$ - mieści się jedno $\mathrm{z}$ najistotniejszych określeń Karola Wojtyły, będące kluczem do zrozumienia wartości ludzkiego działania.

\section{Samostanowienie jako warunek ludzkiego działania i samowychowania}

Typowe dla personalistycznej perspektywy jest zaakcentowanie antropocentrycznego charakteru działania czy - może bardziej precyzyjnie - zwrócenie uwagi na wartość osoby, która działa. Zdaniem krakowskiego filozofa „wartość personalistyczna [działania - K.S.] polega na tym, że w czynie osoba samą siebie aktualizuje,

12 Jak zauważa Rocco Buttiglione we wstępie do dzieła Karola Wojtyły, „odkrycie działania osoby, jej przyczynowości sprawczej i odpowiedzialności za swe czyny jawi się [...] jako fenomenologiczne potwierdzenie metafizyki możności i aktu w jej uszczegółowieniu przybierającym postać ludzkiego suppositum. Osoba nie jest tylko «sceną», na której «wydarzają się» czucia i przeżycia wartości, lecz jest zarazem aktywnym podmiotem tychże uczuć i przeżyć, ona może pomiędzy nimi wybierać, pozwalając się kierować poznaną przez siebie prawdą" (Buttiglione 1994, s. 17).

13 O intencjonalności jako jednej z cech wyróżniających człowieka niemiecki filozof Robert Spaemann pisze następująco: „Osoby należą do istot mających stronę wewnętrzną, to znaczy do istot, które przeżywają. [...] Intencjonalności nie można adekwatnie opisać jako stanu psychicznego. Do jej definicji należy to, co w stanie intencjonalnym jest myślane lub zamierzane" (Spaemann 2001, s. 60). 
w czym wyraża się właściwa jej struktura samoposiadania i samoopanowania” (Wojtyła 1985, s. 329).

Wcześniej pisze on również o tym, że sprawczość jest pochodną wolności: „Wolność właściwa człowiekowi, wolność osoby poprzez wolę, utożsamia się z samostanowieniem jako z rzeczywistością doświadczalną i najpełniejszą, i najbardziej podstawową zarazem" (Wojtyła 1985, s. 143). Jest to o tyle istotne, że nie ma wychowania bez samostanowienia; a zatem tylko wolne działanie człowieka będzie w stanie wyrazić się w działaniu edukacyjnym, jakim jest samowychowanie. Ponownie Karol Wojtyła podkreśla odmienne typy dynamizmów regulujące aktywności bytów ożywionych: w przypadku natury jest to konieczność, w przypadku człowieka - samostanowienie (Wojtyła 1985, s. 144). Więcej: w przypadku zwierząt, jak zauważa filozof, nie można tak naprawdę mówić o działaniu w pełnym tego słowa znaczeniu. Być może to dzisiaj właśnie jeden z najbardziej palących, a jednocześnie silniej kwestionowanych wątków debaty toczącej się wokół problematyki filozofii działania. Z tego względu warto zacytować tę myśl in extenso: „Na poziomie dynamizmu samej natury nie ma działania, nie ma czynów, są tylko, ściśle biorąc, «uczynnienia», jest w każdym wypadku swoista suma tego, co się «dzieje» w podmiocie - i co tworzy odrębną całość życia i dynamizmu tegoż podmiotu” (Wojtyła 1985, s. 144). I w innym miejscu: „Instynkt [u zwierząt K.S.] scala i orientuje w jednostce zwierzęcej to wszystko, co ściśle biorąc dzieje się w niej, w całokształt, który może wywołać wrażenie działania, chociaż jest tylko - wspaniałą na swój sposób - koordynacją uczynnień. O działaniu (czyli o czynie) w ścisłym tego słowa znaczeniu - to jest w takim, do jakiego podstawę znajdujemy w całościowym doświadczeniu człowieka - może być mowa tylko w wypadku samostanowienia. W wypadku kierowania przez instynkt zachodzi pewna zewnętrzna analogia działania: odnośny dynamizm wygląda jak działanie, sama jednakże istota działania-czynu w nim się nie realizuje” (Wojtyła 1985, s. 145).

Specyfiką przedstawionego tutaj rozumowania jest płynne przechodzenie od filozofii działania do filozofii człowieka (wizji antropocentrycznej) i od filozofii człowieka do filozofii działania (w szerokiej perspektywie). Tam, gdzie analogia w zakresie działania może przesądzić o zrównaniu ze sobą ludzi i zwierząt, wszystko pozostaje na swoim miejscu i różnica nie zostaje rozmyta, działania nie stają się tożsame. Po ustaleniu i potwierdzeniu differentia specifica można postawić pytanie, jakie implikacje do pedagogiki wnosi filozoficzna refleksja Wojtyły.

Osoba i czyn to nie jest, rzecz jasna, tekst pedagogiczny, choć jako tekst filozoficzny daje podstawy do prowadzenia rozważań dotyczących sfery edukacji. Trudno sobie wyobrazić rzetelną dyskusję o wychowaniu bez wcześniejszego ustalenia znaczenia tak podstawowych terminów jak: „wolność człowieka”, „istota wychowania” czy „sprawczość” w oparciu o bazowe pojęcia filozoficzne. Wydaje się, że tu właśnie znajduje się punkt styku filozoficznej refleksji z pedagogiką. Praktycznie we wszystkich istniejących nurtach pedagogicznego myślenia edukacja ujmowana jest jako domena wolności; wolności być może czasem zawłaszczanej, poddawanej 
manipulacji, negowanej czy absolutyzowanej... Przywołana w cytowanym tekście intencjonalność, zdolność do samostanowienia, jest podstawowym warunkiem samowychowania. Odpowiedzialność zaś, można dopowiedzieć, jest aktem właściwym tylko dla osób wolnych. Ujmując to językiem Wojtyły: wolność wyraża się w sprawczości, a sprawczość pociąga za sobą odpowiedzialność. Ta zapomniana nieco triada pojęć wyraża adekwatnie te cechy, które właściwe są działaniu osoby.

\section{Spełnienie czynu jako wartość i praca nad sobą jako działanie wartościowe}

Wydaje się, że pomimo pozornie elastycznych czy wręcz otwartych ram pedagogicznej debaty pluralizm oglądu szkoły jako fenomenu społecznego nieuchronnie dryfuje w stronę jednostronnej wykładni. Badacze zajmujący się analizą dyskursów o edukacji zwracają uwagę na dominującą funkcjonalistyczną interpretację szkoły, zogniskowaną wokół kategorii rozumu instrumentalnego (Zamojski 2015). W klasycznym już ujęciu tej kategorii aktywność rozumu instrumentalnego rozumiana jest jako „dążenie do opanowania przez człowieka świata przedmiotów oraz rozszerzania kontroli nad nimi” (Kwaśnica 2007, s. 45). Przywiązanie do utylitarystycznego klucza kształcenia nie tylko zubaża pedagogiczny dyskurs, ale także nie dopuszcza do niego innych rodzajów racjonalności. Na tym tle brzmi co najmniej dziwnie, jeśli nie paradoksalnie, wypowiedź Wojtyły dotycząca wartości działania przez osobę: „samo spełnianie czynu przez osobę stanowi podstawową wartość. Można by ją nazwać personalistyczną wartościa czynu - personalistyczną albo osobowa [...]. Wartość ta tkwi w samym spełnianiu czynu przez osobę - że człowiek działa w sposób sobie właściwy. A więc - że działanie to posiada charakter autentycznego samostanowienia, że realizuje się w nim transcendencja osoby" (Wojtyła 1985, s. 327). W przywołanym fragmencie autor Osoby i czynu podkreśla, że ważny jest podmiot, który działa, i to, że działa. W logikę wynikowości nie wpisują się jednak sformułowania typu „wartość pracy nad sobą”, „wartość postanowień”. Polityka oświatowa zorientowana neoliberalnie pomija transcendentność oraz intencjonalność osoby, która w jakimś sensie zanika przykryta przez swoje wymierzalne działanie.

Depersonalizacyjne i dehumanizacyjne tendencje w pedagogice i edukacji (Kowal 2014) nie dotyczą tylko, jak się powszechnie wydaje, masowości i anonimowości kształcenia, biurokracji czy w ogóle prób przenoszenia form kształcenia w rzeczywistość wirtualną (edukacja na odległość, zastępowanie nauczycieli różnego rodzaju elektronicznymi stymulatorami). Problem związany z kształceniem sięga o wiele głębiej i dotyczy sfery celowości: czy jest w ogóle możliwe autoteliczne działanie edukacyjne? Czy raczej tylko zawsze - edukacja na potrzeby rynku? Czy wartość edukacji wyraża się w samostanowieniu o sobie, czy raczej w tym, jak osoba potrafi pokazać swoje umiejętności - kapitał społeczny, kompetencje społeczne etc.? Czy edukacja jest - podobnie jak inne dziedziny gospodarki - produkcją „dóbr widzialnych"? Czy prawdziwa (humanistyczna) edukacja nie zawiera się przede 
wszystkim w nabywaniu „dóbr niewidzialnych"14? Warto zaznaczyć, że nawet w humanistycznie zorientowanych nurtach edukacji niepokój co do prawdziwych przesłanek ukrytych za działaniem, a zarazem pytanie o prawdziwy cel kształcenia, wcale nie zanikają: „Jest pewien problem, w który niekiedy dajemy się wmanewrować. Mianowicie, staramy się uzasadniać edukację. Traktować wykształcenie jako zawsze służebne. Również w wersjach «krytycznych», jak w przypadku Marthy Nussbaum, która stwierdza, że osoby poddane lekcjom sokratejskim lepiej radzić będą sobie na rynku pracy. Są bardziej elastyczne, mobilne, szybciej orientują się w zmieniającej się rzeczywistości itd. Taka narracja pojawia się niekiedy w ramach «pedagogiki emancypacyjnej», gdzie przedsiębiorczość («odpowiednio rozumiana») rozwija zarazem jednostkę, co «przy okazji» służy rynkowi” (Szwabowski 2015).

Być może byłoby sporym nadużyciem stwierdzenie, że problem ze zrozumieniem wartości działania edukacyjnego niepodlegającego kryterium użytkowości skorelowany jest z problemem postrzegania wartości osoby jako takiej. Jednocześnie być może rzeczywiściekryzys patrzenia na edukacjęjest spowodowanyograniczeniem siędo tego, co widzialne. Tymczasem działanie osoby, także to, które jest (samo)wychowaniem, nie wyczerpuje się w zewnętrzności. Personalistyczny charakter działania najbardziej uwidacznia się w sferze aktów wewnętrznych osoby.

\section{Znaczenie aktów wewnętrznych i edukacja jako sfera intymności}

Końcowe rozważania zawarte w tej pracy dotyczą zagadnienia, jak się wydaje, całkowicie pomijanego w głównym nurcie debaty o edukacji, które wynika ze specyfiki bycia osobą. Ponownie źródłem refleksji są słowa Karola Wojtyły: „Każdy czyn jest uzewnętrznieniem osoby, choćby dokonywał się w sposób li tylko wewnętrzny i zasługiwał na nazwę actus internus. Wypada zauważyć, że nazwę taką nadaje się w podręcznikach tym czynom, które dokonują się bez zaangażowania tego wszystkiego w człowieku, co działaniu nadaje niejako znamię widzialności. Dzięki temu znamieniu czyny zasługują tradycyjnie na nazwę actus externus. Jednakże widzialność nie jest ani jedynym, ani tym bardziej właściwym sprawdzianem uzewnętrznienia, jakie stwierdzamy w czynie w stosunku do osoby. Osoba bowiem nie tylko uprzedmiotawia się w każdym swym czynie, ale też uzewnętrznia, choćby był to czyn w świetle kryterium widzialności - najzupełniej wewnętrzny" (Wojtyła 1985, s. 142).

Kategoria czynów wewnętrznych, przywołanych i opisanych w cytowanym fragmencie, analogicznie wpisuje się w obszar samowychowania - myśli, intencji, postanowień, które zarządzają tą sferą aktywności człowieka. Przyjęcie do wiadomości, że kryterium widzialności nie może być jedyną formą „kontroli” tego, czy

14 Tak również zatytułowana jest książka Juana Luisa Lordy Humanizm. Dobra niewidzialne, w której autor przez dobra niewidzialne rozumie dar przyjaźni, życie intelektualne, uczciwość (Lorda 2011). 
i jak osoba działa, pozwala na powrót do klasycznej, ale jakże potrzebnej koncepcji edukacji jako sprawy intymnej.

Edukacja jest sprawą intymną ${ }^{15}$, ale bynajmniej nie dlatego, że dotyczy spraw intymnych (jak, na przykład, przekazywanie życia), że uczy adekwatnego wyrażania siebie, również poprzez ciało (wychowanie do wstydliwości). Edukacja jest dowodem na to, że w człowieku istnieje jakaś przestrzeń wewnętrzna - przestrzeń wolności; obszar przemyśleń, refleksji, wewnętrznego mocowania się i mierzenia z sobą samym, pokonywania swoich słabości. Jeśli, jak starano się zaznaczyć, edukacja jest szczególnym rodzajem działania - działaniem etycznym, to dotyczy to również sfery świadomości człowieka.

\section{Podsumowanie}

Celem pracy było zwrócenie uwagi na wartość personalistycznej koncepcji działania oraz przedstawienia jej implikacji dla pedagogii. Potrzebna jest zmiana spojrzenia na edukację, przezwyciężająca redukcyjne ujęcie osoby i jej działania, być może poprzez powrót do dzieła Osoba i czyn. Ten pochodzący z 1969 roku tekst doskonale wpisuje się w rosnące zainteresowanie kategorią działania oraz obecność w publicznym dyskursie takich tematów jak: sprawności etyczne, kompetencje społeczne nauczycieli, znaczenie mądrości praktycznej, edukacja rozumiana jako praxis etc. Z fenomenologicznej analizy działania osoby wyłania się również jej pogłębiony opis, a bez pogłębionej wizji osoby uprawianie pedagogiki wydaje się niemożliwe.

Nasycenie kształcenia myśleniem neoliberalnym oraz zapożyczenie do jego oceny pozanormatywnych (pozaedukacyjnych) języków opisu prowadzi do inicjowania projektów badawczych, które stawiają sobie za cel analizę podporządkowania edukacji różnym ideologiom ${ }^{16}$. Co ciekawe, krytyczne postulaty rewindykacji

15 Do rozumienia edukacji jako sfery intymnej powraca również Aleksander Nalaskowski w artykule Szkoły jednopłciowe - powrót do intymności kształcenia. Zdaniem badacza „nauczanie i uczenie się to czynność, proces, działanie niezwykle osobiste, a niekiedy intymne. Uczenie się polega na pokonywaniu własnych niedostatków, nieumiejętności, a także słabości”. I dalej: „Wraz ze zmianami obyczajowymi, mentalnymi i prawnymi, których etiologii nie jesteśmy w stanie obecnie zrozumieć (jeśli wyjąć teorie spisków czy koncepcję totalnej wolności będącej rzekomo potrzebą każdej jednostki), właśnie proces edukacji, czyli kształcenia i wychowania, uległ niemal skrajnej deintymizacji. Z procesu osobistego i niezwykle indywidualnego stał się niemal przezroczystym tunelem przebiegającym w samym środku życia społecznego" (Nalaskowski 2013, s. 173-174).

16 Takie zadanie postawił sobie interdyscyplinarny zespół, tworząc projekt „Subsumacje edukacji”. Jak piszą autorzy tego projektu, „w jego ramach staramy się przebadać możliwe formy podporządkowania edukacji. Głównym celem naszych badań jest opracowanie i analityczne wykorzystanie kategorii subsumcji, zbadanie semantycznych, ontologicznych i performatywnych implikacji w odniesieniu do problematyki edukacyjnej. Pragniemy zwrócić uwagę na społeczne, polityczne i etyczne wymiary podporządkowywania procesów edukacyjnych, zapytać o możliwe sposoby użycia i kontrużycia analizowanej kategorii, jak również o możliwe w danej perspektywie 
celów, jakie stawiane są pedagogice, edukacji, wychowaniu, pochodzą głównie z lewicowych czy nawet anarchizujących środowisk, które przyznają się wprost do marksistowskiej orientacji (Chutorański, Szwabowski, Moroz 2014). Ten ruch świadomej krytyki paradoksalnie jednak sprzyja odnowieniu konserwatywnego myślenia, poszukiwaniu status quo, pytaniu o fundamenty.

Być może zasygnalizowane $\mathrm{w}$ tekście trudności $\mathrm{z}$ adekwatnym dla edukacji kontekstem stanowią swego rodzaju interpelację ponad podziałami, wokół której warto łączyć badawcze poszukiwania. W tym sensie odwołanie się do szeroko rozumianego nurtu personalistycznego jest jak najbardziej na miejscu. Jak zauważył Marian Nowak, „tak nacechowana pedagogika pozwala na przezwyciężenie myślenia ilościowego i przyczynowego w naukach o wychowaniu, przyczynia się do lepszego zrozumienia samego procesu wychowania, podnosi kwestie jakościowe w wychowaniu, a także może wnieść stan równowagi w ogólny klimat pedagogiczny, zwracając uwagę na te wartości, które są pomijane w aktualnych tendencjach rozwojowych" (Nowak 1999, s. 486).

\section{Bibliografia}

Bakke M. (2010). Bio-transfiguracje. Sztuka i estetyka posthumanizmu. Poznań: Wydawnictwo Naukowe UAM.

Buttiglione R. (1994). Kilka uwag o sposobie czytania „Osoby i czynu”, tłum. Styczeń T. W: Styczeń T. i in. (red.). „Osoba i czyn” oraz inne studia antropologiczne. Lublin: Wydawnictwo Towarzystwa Naukowego Uniwersytetu Lubelskiego, s. 11-42.

Chutorański M., Szwabowski O., Moroz J. (2014). O projekcie „Subsumacje edukacji”. „Parezja”, nr 2, s. 139-146.

Czerepaniak-Walczak M. (red.). (2013). Fabryki dyplomów czy universitas? O „nadwiślańskiej” wersji przemian w edukacji akademickiej. Kraków: Oficyna Wydawnicza „Impuls”.

Gutek G.L. (2007). Filozoficzne i ideologiczne podstawy edukacji, tłum. Kacmajor A., Sulak A. Gdańsk: GWP.

projekty emancypacyjne. [...] Za szczególnie istotne uznajemy następujące problemy: 1. Jakie są znaczenia i formy subsumcji (Marks, Negri, Tomba, Foucault i inni)? 2. Rodzaje podporządkowywania praktyk i teorii (w) edukacji. Czy możliwe jest wskazanie ostatecznej instancji subsumcji procesów społecznych (kapitał, biowładza, władza suwerena, natura i inne)? 3. Jakie są relacje subsumcji zachodzące pomiędzy fundamentalnymi kategoriami epistemicznymi a edukacją? 4. Jakie wymiary i formy przyjmuje podporządkowanie instytucji edukacyjnych i pracy w tych instytucjach (pracy uczniów, nauczycieli, studentów, wykładowców i innych)? 5. Czy i jak można pomyśleć edukację wolną od podporządkowania procesom społecznym i/lub ekonomicznym? 6. Czemu powinna (w sensie etycznym/politycznym) być podporządkowana edukacja? 7. Jakie istnieją i jakie mogą istnieć formy oporu przeciwko podporządkowaniu?” (Chutorański, Szwabowski, Moroz 2014, s. 139-140). 
Klichowski M., Przybyła M. (2013). Cyborgizacja edukacji-próba konceptualizacji. „Studia Edukacyjne”, nr 24, s. 143-154.

Klichowski M. (2014). Narodziny cyborgizacji. Nowa eugenika, transhumanizm i zmierzch edukacji. Poznań: Wydawnictwo Naukowe UAM.

Kupisiewicz C., Kupisiewicz M. (red.). (2009). Słownik pedagogiczny. Warszawa: Wydawnictwo Naukowe PWN.

Kowal S. (2014). Personalizacja kształcenia. Wystapienie na I Ogólnopolskim Kongresie Tutoringu, Warszawa 16-17 maja 2014. Organizator: Collegium Wratislaviense.

Kunowski S. (2004). Podstawy współczesnej pedagogiki. Warszawa: Wydawnictwo Salezjańskie.

Kwaśnica R. (2007). Dwie racjonalności. Od filozofii sensu ku pedagogice ogólnej. Wrocław: Wydawnictwo Naukowe Dolnośląskiej Szkoły Wyższej Edukacji TWP.

Kwieciński Z. (2012). Pedagogie postu. Preteksty - konteksty - podteksty. Kraków: Oficyna Wydawnicza „Impuls”.

Lorda J.L. (2011). Humanizm. Dobra niewidzialne, tłum. Roszak P. Toruń: Kunke Poligrafia.

Michałowska D.A. (2013). Neoliberalizm i jego (nie)etyczne implikacje edukacyjne. Poznań: Wydawnictwo Naukowe UAM.

Nalaskowski A. (2013). Szkoły jednopłciowe - powrót do intymności kształcenia. „Paedagogia Christiana”, nr 1/31, s. 1-8.

Nowak M. (1999). Wiedza o wychowaniu w perspektywie pedagogiki personalistycznej. W: Gnitecki J., Rutkowiak J. (red.). Pedagogika i edukacja wobec nadziei i zagrożeń współczesności. Materiały z III Ogólnopolskiego Zjazdu Pedagogicznego. Warszawa: Polskie Towarzystwo Pedagogiczne.

Pilch T. (red.). (2003). Encyklopedia pedagogiczna XX wieku. Warszawa: Wydawnictwo Akademickie „Żak”.

Podsiad A. (200o). Słownik terminów i pojęć filozoficznych. Warszawa: Instytut Wydawniczy Pax.

Sośnicki K. (1967). Istota i cele wychowania. Warszawa: Nasza Księgarnia.

Spaemann R. (2001). Osoby. O różnicy między kimś a czymś, tłum. Merecki J. Warszawa: Oficyna Naukowa.

Styczeń T. i in. (red.). (1994). „Osoba i czyn” oraz inne studia antropologiczne. Lublin: Wydawnictwo Towarzystwa Naukowego Uniwersytetu Lubelskiego.

Szwabowski O. Edukacja jako oszustwo, dostępny na: http://www.praktykateoretyczna.pl/oskar-szwabowski-edukacja-jako-oszustwo/ (otwarty 16.05.2015).

Wojtyła K. (1985). Osoba i czyn. Kraków: Polskie Wydawnictwo Teologiczne.

Wołk Z. (2005). Świat jako market. Edukacja, praca, doradzanie w neoliberalnej rzeczywistości. W: Kargulowa A., Kwiatkowski S.M., Szkudlarek T. (red. nauk.). Rynek i kultura neoliberalna a edukacja. Kraków: Oficyna Wydawnicza „Impuls”, s. $73-86$. 
Zamojski P. Dialektyka funkcjonalizacji szkoły. Tezy do wykładu dostępne na: http:// subsumcjeedukacji.blogspot.com/2014/04/wykad-dra-piotra-zamojskiego-pt. html (otwarty 16.05.2015).

Zamojski P. (2010). Miejsce normatywności w dyskursie pedagogiki: ku pojmowaniu działania edukacyjnego jako kwestii etycznej. W: Michalak J. (red. nauk.). Etyka i profesjonalizm $w$ zawodzie nauczyciela. Łódź: Wydawnictwo Uniwersytetu Łódzkiego.

\title{
THE ACTING PERSON AS A DIFFERENTIATING CATEGORY AND ITS IMPLICATIONS FOR PEDAGOGY
}

\begin{abstract}
The aim of this paper is to demonstrate, on the basis of Karol Wojtyła's work The Acting Person, the validity of returning to the personalistic understanding of the acting person as the necessary philosophical tradition to restore the value of upbringing in the contemporary cultural context. The starting point is the assumption that education has been assigned in a neoliberal, technological, and eugenic context of public debate, what has reduced the meaning of educational acting. These three positions are linked by common understanding of education focused rather on the result than on the process itself and aimed to regulate this process and even take control over it. Only if human acting - contrary to the assumptions of transhumanism - is recognized as a differentiating category, which means that it really differs from both animal activity and machine activity, it is possible to defend the rationality of human activity in the area of upbringing.
\end{abstract}

Key words: philosophy of acting, personalism, upbringing, self-education, neoliberalism, eugenics, cyborgization of education.

Katarzyna Szymala - absolwentka filologii polskiej UJ. Od kilku lat związana z edukacją niepubliczną. Pracuje w Szkole Podstawowej, Gimnazjum i Liceum „Strumienie” Stowarzyszenia STERNIK w Józefowie, gdzie zajmuje się tutoringiem rodzinnym oraz kształceniem nauczycieli w zakresie kompetencji wychowawczych. Publikowała m.in. w „Ruchu Pedagogicznym”, „Studiach z Teorii Wychowania”, „Przeglądzie Pedagogicznym” oraz „Parezji”. Jej zainteresowania naukowe koncentrują się wokół filozofii edukacji, teorii oraz praktyki wychowania. 